\title{
Geological observations in the southern West Greenland basement from Ameralik to Frederikshåb Isblink in 2008
}

\author{
Nynke Keulen, Anders Scherstén, John C. Schumacher, Tomas Næraa and Brian F. Windley
}

In 2008, the Geological Survey of Denmark and Greenland began a project in collaboration with the Bureau of Minerals and Petroleum of Greenland with the aim to publish a webbased, seamless digital map of the Precambrian bedrock between $61^{\circ} 30^{\prime}$ and $64^{\circ} \mathrm{N}$ in southern West Greenland. Such a map will be helpful for the mineral exploration industry and for basic research. Producing an updated digital map requires additional field work revisiting key localities to collect samples for geochemistry, geochronology and metamorphic petrology. The new data will help us to test and refine existing models and improve general understanding of the geological evolution of the area. Here we summarise some results from the 2008 field activities between Ameralik in the north and Frederikshåb Isblink in the south (Fig. 1). The area was mapped in the 1960s and 1970s, and although the 1:100 000-scale maps are of excellent quality, they do not include more recent developments in geochronology, thermobarometry and geochemistry. A notable exception is the Fiske- næsset complex (Fig. 1), which has received considerable attention after it was first mapped (Ellitsgaard-Rasmussen \& Mouritzen 1954; Windley et al., 1973; Windley \& Smith, 1974; Myers 1985). New tectonic models have been developed since the original 1:100 000 maps were produced, and the tectonic evolution has been commonly explained in terms of terrane accretion (Friend et al. 1996). Friend's model defines a number of boundaries

Fig. 1. Simplified geological map of the central part of the North Atlantic craton in southern West Greenland showing the main rock components, patterns of metamorphic facies and three crustal blocks (modified after Windley \& Garde 2009). that separate terranes of different age and origin and which might have contrasting tectono-metamorphic histories prior to terrane accretion. The current project area includes the northern part and proposed boundary of the Tasiusarsuaq terrane, which was amalgamated with the terranes to the north at $2.72 \mathrm{Ga}$, when regional metamorphism affected the region (Friend et al. 1996). In addition, Windley \& Garde

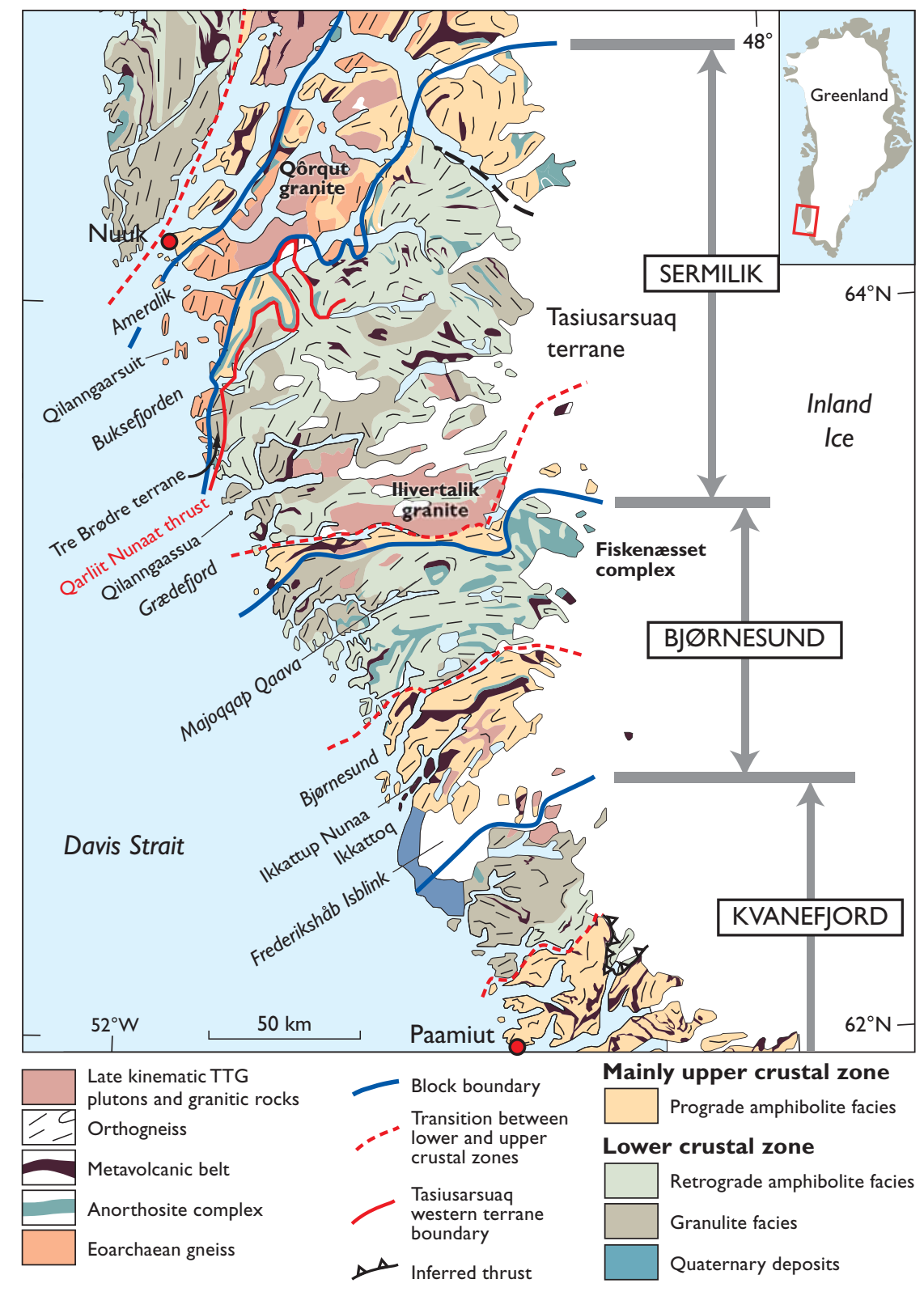




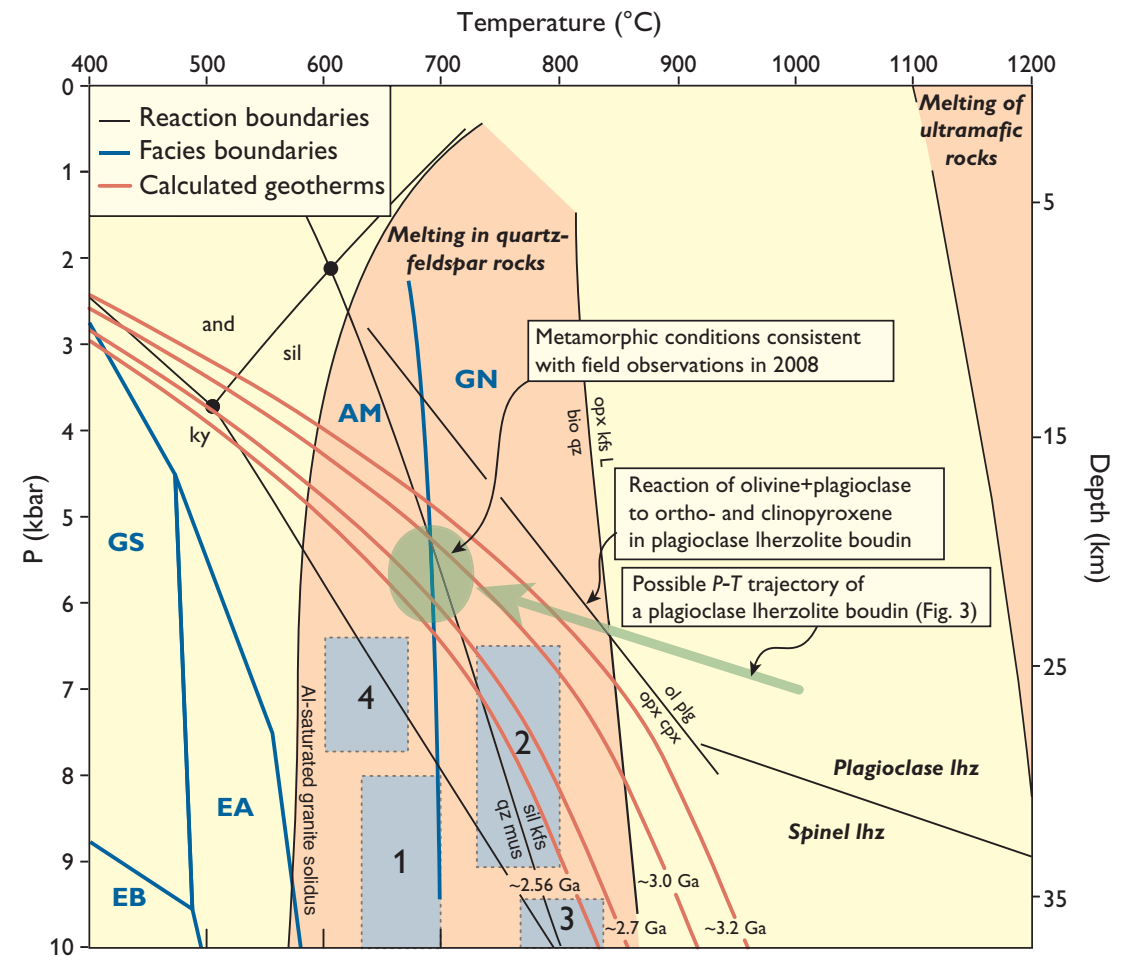

(2009) proposed a model in which a series of blocks represent crustal sections that (except for the Sermilik block; Fig. 1) display a systematic metamorphic progression from amphibolite facies to granulite facies rocks from south to north. Each block represents a number of island and continental arcs that were amalgamated by collision into the growing North Atlantic craton. In their model, the project area consists of the Sermilik, Bjørnesund and Kvanefjord blocks, where each block represents a combination of lateral and vertical crustal growth. However, contrary to the terrane model, two blocks can have a common origin.

\section{Quartzo-feldspathic rocks}

Grey tonalite-trondhjemite-granodiorite-type gneisses (TTG) have intrusive ages of 2.92-2.84 Ga that represent the main crust-generating period (Schiøtte et al. 1989; Næraa \& Scherstén 2008). There is growing evidence from zircon U-Pb-Hf geochronology for an older previously unrecognised Mesoarchaean crustal component within the Tasiusarsuaq terrane (Næraa \& Scherstén, unpublished data). The extent of the older component is currently unclear, but it is apparently most widespread in the northern part of the terrane. In addition, a number of strongly deformed and veined tonalitic gneisses of presumed early Neoarchaean age are younger, about $2.72 \mathrm{Ga}$, and formed from older pre-existing crust.

Granite (sensu lato) intrusions are variably deformed but post-date the majority of the grey gneisses. The main granite, the Ilivertalik augen granite, has feldspar megacrysts, and is
Fig. 2. Ranges of $P-T$ estimates from previous work by Wells (1979), Griffin et al. (1980) and Riciputi (1990); geotherms based on measured and estimated contents as a function of time of radiogenic elements in basaltic and felsic Greenland rocks using methods of Kamber et al. (2005). The calculations are based on a crustal thickness of $40 \mathrm{~km}$ and a two-layer model with $10 \mathrm{~km}$ of mafic rocks at the base of the crust overlain by $30 \mathrm{~km}$ of felsic rocks. Depths in kilometres are based on an average crustal density of $2.75 \mathrm{~g} / \mathrm{cm}^{3}$. Parameters: mantle heat flow: $20 \mathrm{~mW} / \mathrm{m}^{2}$; mafic and felsic rockheat production are: 0.262 and $3.478 \mu \mathrm{W} / \mathrm{m}^{3}$ at $3.2 \mathrm{Ga}$ (possible maximum age for this part of the terrane), 0.244 and $3.254 \mu \mathrm{W} / \mathrm{m}^{3}$ at $3.0 \mathrm{Ga}$, 0.220 and $2.945 \mu \mathrm{W} / \mathrm{m}^{3}$ at $2.7 \mathrm{Ga}, 0.210$ and $2.811 \mu \mathrm{W} / \mathrm{m}^{3}$ at $2.56 \mathrm{Ga}$ (age of the Qôrqut granite). The numbered blue fields represent the ranges of $P-T$ estimates: $1=$ Sermilik (Griffin et al. 1980); 2 = Sermilik and Qilanngaassua (Riciputi et al. 1990); 3 = Sermilik (Wells 1979); 4 = Qilanngaarsuit (Wells 1979). AM, amphibolite facies; and, andalusite; bio, biotite; $\mathbf{c p x}$, clinopyroxene; $\mathbf{E A}$, epidoteamphibolite facies; EB, epidote-blueschist facies; GN, granulite facies; GS, greenschist facies; kfs, K-feldspar; ky, kyanite; 1, liquid lhz, lherzolite; mus, muscovite; ol, olivine; $\mathbf{o p x}$, orthopyroxene; $\mathbf{p l g}$, plagioclase; $\mathbf{q z}$, quartz; sil, sillimanite.

in some places orthopyroxene-bearing and has been dated to 2.8 Ga (Pidgeon \& Kalsbeek 1976; Næraa \& Scherstén, unpublished data). The main volume of this granite intrudes the Sermilik block, but satellite intrusions, including the type locality at Ilivertalik mountain, are found in the Bjørnesund block, implying that these blocks were a single crustal unit by 2.8 Ga. At Ilivertalik mountain, Kalsbeek \& Myers (1973) suggested that the intrusion was charnockitic and was emplaced under granulite-facies conditions.

Mica schists, commonly with garnet or sillimanite, occur throughout the area. These were originally mapped as having sedimentary protoliths. To our knowledge, all recognised structures in these rocks are tectono-metamorphic, and their supracrustal origin seems to have been mostly inferred from their common relationship with amphibolites or their aluminium-rich or quartzitic compositions.

\section{Amphibolites and metagabbro-anorthosites}

Supracrustal rocks with a range of compositions occur throughout the area, but are dominated by amphibolites. Preservation varies, with readily identified primary textures in 
some areas and amphibolite lenses in others. The Ikkattup Nunaa belt on the islands in the Ikkattoq fjord just north of Frederikshåb Isblink (Fig. 1) is one of the best-preserved volcanic belts in the region (Andersen \& Friend's 1973 Ravns Storø belt). Pillow lavas and volcanic bombs are well preserved here, and these rocks likely formed in shallow water with partly explosive volcanism. Rocks with calc-alkaline basaltic to andesitic compositions predominate (K. Szilas et al., unpublished data 2009), and analytical results suggest a convergent margin setting with an age of $2.91 \pm 0.01 \mathrm{Ga}$ (Nutman et al. 2004). In 2008 we discovered that some major amphibolite belts at Majoqqap Qaava (Fig. 1) contain two components, namely lithic tuff-dominated, metavolcanic rocks and massive homogeneous amphibolite sheets, which are similar to the two main components of the Ikkattup Nunaa belt, thus a common arc origin is likely.

The Fiskenæsset complex is a layered igneous complex containing ultramafic rocks, gabbros, leucogabbros, anorthosites and chromitites, which formed largely by cumulate processes (Myers 1985). In 2008, we established that the lower main ultramafic unit, best exposed at Majoqqap Qaava, consists of a succession of layered dunites intruded by a major sill complex that comprises more than 25 clinopyroxene-hornblende sills, some of which are up to $10 \mathrm{~m}$ thick. The sills contain xenoliths of dunite, send apophyses into adjacent dunites and have discordant contacts against layered dunites. This observation means that the early history of the Fiskenæsset complex involved intrusion of a second, hydrous magma batch into earlier crystallised, olivine-rich cumulates.

Meta-gabbros and meta-anorthosites of the Fiskenæsset complex are closely associated with amphibolites of supra-

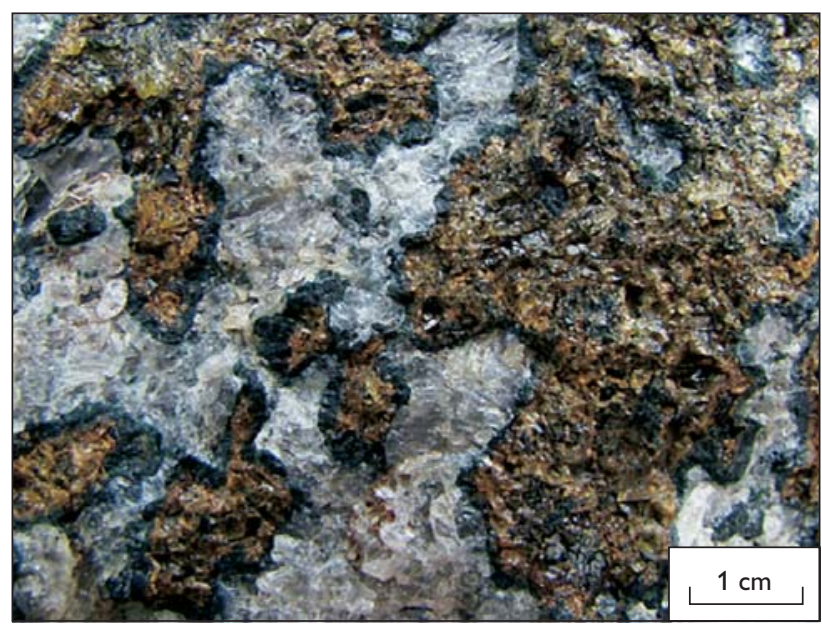

Fig. 3. Spinel-bearing plagioclase lherzolite showing the breakdown of olivine and plagioclase to form coronas of clinopyroxene and orthopyroxene. The stability limits of the plagioclase lherzolite are below c. 9 kbar and $1200^{\circ} \mathrm{C}$, and the reaction would have occurred between about $700^{\circ} \mathrm{C}, 4 \mathrm{kbar}$ and $870^{\circ} \mathrm{C}, 7 \mathrm{kbar}$. Location at $63.932^{\circ} \mathrm{N}, 51.219^{\circ} \mathrm{W}$. crustal origin, and they could be part of the same magmatic system. Escher \& Myers (1975) believed that the Fiskenæsset complex was intrusive into the amphibolites. However, the observed contacts are tectonic, and direct evidence for primary intrusive relationships is lacking. Clearly, discordant anorthosite dykes cross-cut strongly deformed metagabbros within the complex (e.g. at $63.1156^{\circ} \mathrm{N}, 50.7155^{\circ} \mathrm{W}$ ). These dykes consist of plagioclase and orthopyroxene and likely post-date all deformation.

\section{Tectono-metamorphic development}

The Qarliit Nunaat thrust forms the boundary between the Tre Brødre and Tasiusarsuaq terranes (Fig. 1; Friend et al. 1996). South of Buksefjorden there is a very high-strain, high-grade shear zone several kilometres wide between the Færingehavn and the Tasiusarsuaq terranes (Stainforth 1977; Crowley 2002). However, on either side of this shear zone, the tectono-metamorphic styles are different; to the north of Buksefjorden we found no evidence for a metamorphic or structural discontinuity. Here, rocks previously considered to be part of the Tre Brødre terrane might therefore be part of the Tasiusarsuaq terrane.

An abrupt change in metamorphic grade, from amphibolite facies just south of Grædefjord to granulite facies a little farther south, within the Tasiusarsuaq terrane, is associated with intensive shearing as predicted in the crustal block model of Windley \& Garde (2009). Confirmation of the model comes from the fact that in 2008 we discovered that the boundary is occupied by a north-dipping, over $250-\mathrm{m}$ wide shear zone with a down-dip lineation, which contains augen gneisses, cataclasites and mylonites. The boundary separates amphibolite facies gneiss with granulite facies relicts to the south from prograde amphibolite facies gneisses to the north, as also predicted by Kalsbeek (1976).

Pressure-temperature $(P-T)$ estimates are sparse in the present field area and focused on pyroxene-garnet assemblages (amphibolites) that are restricted to upper amphibolite and granulite facies. Figure 2 shows the locations of estimated geotherms for a $40 \mathrm{~km}$ thick crust. The geotherms that bracket the (3.0-2.7 Ga) metamorphism suggest pressures of 5-6 kbar for the conditions of the amphibolite facies to granulite facies transition. These $P-T-t(t=$ time $)$ conditions are consistent with field observations, e.g. the only aluminosilicate phase found in 2008 was sillimanite, and the observed peak assemblages are consistent with conditions near the amphibolite facies and granulite facies transition at intermediate pressure.

Granulite-facies rocks occur more rarely than suggested on the current 1:100 000 scale maps, although, in the area around the Fiskenæsset complex granulite-facies rocks are 
abundant. Some of the area designated as granulite facies contains amphibolite-facies assemblages, but is interpreted to have once attained granulite-facies conditions. However, part of the rocks previously considered retrograde from granulitefacies rocks might better be interpreted as prograde amphibolite-facies rocks that never reached granulite-facies conditions. Full analysis of the $P-T-t$ trajectories will require detailed textural and chemical analysis of these rocks.

Garnet-bearing mica schists and amphibolites from Ameralik fjord and Frederikshåb Isblink suggest garnet growth at the expense of plagioclase, which is consistent with a metamorphic event dominated by pressure increase. These observations are best explained by thrust tectonics. Evidence for isobaric or near-isobaric cooling was observed in reaction textures of the plagioclase lherzolite from north of Buksefjorden described in Fig. 3. The lherzolite occurs as a boudin within a refolded zone of amphibolite and ultramafic rocks in grey gneiss. Ultramafic boudins are associated with pegmatite dykes, and this resulted in alteration of the ultramafic rocks. Similar corona textures were noted at Majoqqap Qaava and were interpreted as late igneous or early metamorphic reactions by Myers \& Platt (1977).

Cataclastic structures are abundant in the area between Ameralik and Frederikshåb Isblink (e.g. Stainforth 1977). Brittle deformation occurs as an overprint of earlier ductile structures. Pseudotachylytes were observed at a few localities, although cohesive fault rocks (cataclasites) are more common.

\section{References}

Andersen, L.S. \& Friend, C. 1973: Structure of the Ravns Storø amphibolite belt in the Fiskenæsset region. Rapport Grønlands Geologiske Undersøgelse 51, 37-40.

Crowley, J.L. 2002: Testing the model of late Archaean terrane accretion in southern West Greenland: a comparison of timing of geological events across the Qarliit nunaat fault, Buksefjorden region. Precambrian Research 116, 57-79.

Ellitsgaard-Rasmussen, K. \& Mouritzen, M. 1954: An anorthosite occurrence from West Greenland. Meddelelser fra Dansk Geologisk Forening 12, 436-442.

Escher, J.C. \& Myers, J.S. 1975: New evidence concerning the original relationships of early Precambrian volcanics and anorthosites in the Fiskenæsset region, southern West Greenland. Rapport Grønlands Geologiske Undersøgelse 75, 72-76.
Friend, C.R.L., Nutman, A.P., Baadsgaard, H., Kinny, P.D. \& McGregor, V.R. 1996: Timing of late Archaean terrane assembly, crustal thickening and granite emplacement in the Nuuk region, southern West Greenland. Earth and Planetary Science Letters 142, 353-365.

Griffin, W.L., McGregor, V.R., Nutman, A.P., Taylor, P. N. \& Bridgwater, D. 1980: Early Archaean granulite-facies metamorphism south of Ameralik, West Greenland. Earth and Planetary Science Letters 50, 59- 74.

Kalsbeek, F. 1976: Metamorphism in the Fiskenæesset region. Rapport Grønlands Geologiske Undersøgelse 73, 34-41.

Kalsbeek, F \& Myers, J.S. 1973: The geology of the Fiskenæsset region. Rapport Grønlands Geologiske Undersøgelse 51, 5-18.

Kamber, B.S., Whitehouse, M.J., Bolhar, R. \& Moorbath, S. 2005: Volcanic resurfacing and the early terrestrial crust: Zircon U-Pb and REE constraints from the Isua Greenstone Belt, southern West Greenland. Earth and Planetary Science Letters 240, 276-290.

Myers, J.S. 1985: Stratigraphy and structure of the Fiskenæsset complex, southern West Greenland. Bulletin Grønlands Geologiske Undersøgelse 150, 72 pp.

Myers, J.S. \& Platt, R.G., 1977: Mineral chemistry of layered Archaean anorthosite at Majorqap qâva, near Fiskenæsset, southwest Greenland. Lithos 11, 59-72.

Næraa, T. \& Scherstén, A. 2008: New zircon ages from the Tasiusarsuaq terrane, southern West Greenland. Geological Survey of Denmark and Greenland Bulletin 15, 73-76.

Nutman, A.P., Friend, C.R.L., Barker, S.L.L. \& McGregor, V.R. 2004: Inventory and assessment of Palaeoarchaean gneiss terrains and detrital zircons in southern West Greenland. Precambrian Research 135, 281-314

Pidgeon, R.T. \& Kalsbeek, F. 1978: Dating of igneous and metamorphic events in the Fiskenaesset region of southern west Greenland. Canadian Journal of Earth Sciences 15, 2021-2025.

Riciputi, L.R., Valley, J.W. \& McGregor, V.R. 1990: Conditions of Archean granulite metamorphism in the Godthab-Fiskenaesset region, southern West Greenland. Journal of Metamorphic Geology 8, 171-190.

Schiøtte, L., Compston, W. \& Bridgwater, D. 1989: U-Pb single-zircon age for the Tinissaq gneiss of southern West Greenland: a controversy resolved. Chemical Geology 79, 21-30.

Stainforth, J.G. 1977: The structural geology of the area between Ameralik and Buksefjorden, southern West Greenland, 480 pp. Unpublished Ph.D. thesis, Exeter University, UK.

Wells, P.R.A. 1979: Chemical and thermal evolution of Archaean sialic crust, southern West Greenland. Journal of Petrology 20, 187-226.

Windley, B.F. \& Garde, A.A. 2009: Arc-generated blocks with crustal sections in the North Atlantic craton of West Greenland: Crustal growth in the Archean with modern analogues. Earth-Science Reviews 93, 1-30.

Windley, B.F. \& Smith, J.V. 1974: The Fiskenæsset complex, West Greenland, Part II. General mineral chemistry from Qeqertarssuatsiaq. Bulletin Grønlands Geologiske Undersøgelse 108, 54 pp.

Windley, B.F., Herd, R.K. \& Bowden, A.A. 1973: The Fiskenæesset complex, West Greenland, Part I. A preliminary study of the stratigraphy, petrology, and whole rock chemistry from Qeqertarssuatsiaq. Bulletin Grønlands Geologiske Undersøgelse 106, 80 pp.

\footnotetext{
Authors' addresses

N.K., A.S.1 \& T.N., Geological Survey of Denmark and Greenland, Øster Voldgade 10, DK-1350 Copenhagen K, Denmark. E-mail: ntk@geus.dk J.C.S., Department of Earth Sciences, University of Bristol, Bristol BS8 1RJ, UK. B.F.W., Department of Geology, University of Leicester, Leicester LE1 7RH, UK. 1Present address: Department of Geology, Lund University, Sölvegatan 12, S-223 62 Lund, Sweden.
} 